\title{
Occurrence of insect pests and activity of selected natural enemieson sugarcane crop in Northern dry zone of Karnataka
}

\author{
N. Shruthi*, A.P. Biradar and Syed Muzammil
}

Department of Agricultural Entomology, College of Agriculture (U.A.S.), Vijayapur (Karnataka) India

\section{ARITCLE INFO}

Received : 14.12 .2017

Revised : 14.03 .2018

Accepted : 22.03.2018

\section{KEY WORDS :}

Survey, Surveillance, Sugarcane pests, Natural enemies
*Corresponding author: shruthientmsc@gmail.com

\begin{abstract}
Studies showed the evidences of high populations of pests on sugarcane viz., early shoot borer (Chilo infuscatellus Snell), root grub (Holotrichia serrata Fabricus), woolly aphid (Ceratovacuna lanigera Zehnter), scale on sugarcane during 2014.Generally, the incidence of woolly aphid, scales and natural enemies was not appeared during seedling stage of crop since it require cold climate and high relative humidity (80-95) and moderate temperature $\left(19\right.$ to $\left.30^{\circ} \mathrm{C}\right)$. Therefore more population density of woolly aphid, scales and natural enemies was gradually increased during vegetative stage.Roving survey indicated that, higher dead heart percent damage of early shoot borer was recorded in Athani while, lower population of early shoot borer was noticed in Vijayapur taluka. The lowest population of root grub was recorded in Vijayapur taluk while the highest population of root grub was recorded in Athani taluka during the Seedling stage. Similarly, the lowest population of woolly aphid was recorded in Muddebihal taluk while the highest population of woolly aphid was recorded in Athani taluka.The higher population of scales was recorded in Basavana Bagewadi talukas while lower population of scales was noticed in Bilagi taluka. Maximum population of Micromusigoratus and Dipha aphidivora was recorded in Jamakhandi and Basavana Bagewadi taluks, while minimum population of M.igoratus and D. aphidivora was recorded in Bilagi and Muddebihal talukas.
\end{abstract}

How to view point the article : Shruthi, N. Biradar, A.P. and Muzammil, Syed (2018). Occurrence of insect pests and activity of selected natural enemieson sugarcane crop in Northern dry zone of Karnataka. Internat. J. Plant Protec., 11(1) : 80-86, DOI : 10.15740/HAS/IJPP/11.1/ 80-86. 